BISMA

(Bisnis dan Manajemen)
Volume 13, Issue 2, April 2021, 148-162

ISSN 2549-7790 (Online)

ISSN 1979-7192 (Print)

DOI: 10.26740/bisma.v13n2.p:148-162

https://journal.unesa.ac.id/index.php/bisma/index

\title{
An exploration of ethnic entrepreneurial values and characteristics in
} MSEs

\author{
Elsye Tandelilin ${ }^{1 *}$, Dwi Ratmawati ${ }^{2}$, Tri Siwi Agustina ${ }^{3}$ \\ ${ }^{1}$ University of Surabaya, Indonesia \\ ${ }^{1,2,3}$ Universitas Airlangga, Indonesia
}

\begin{abstract}
Entrepreneurship is one aspect that can encourage economic growth in a country through the creation of goods and services, it can improve the welfare of society. However, the survival of micro and small enterprises (MSEs) is still lower. Even though the number of MSEs in Indonesia has increased, the failure elevates. Variables that can increase the success of MSEs include the values and characteristics of the entrepreneur. This paper explores the entrepreneurial values and characteristics of Chinese, Javanese, and Madurese ethics in MSEs. This study uses a case study approach by using in-depth interviews to explore detailed information. The data source is primary data with six informants from three different ethnicities (Chinese, Javanese, and Madurese). The results demonstrate that Indonesian Chinese entrepreneurs uphold values and dominant perseverance, hard work, guanxi, honesty, personal trust, and confucianism values. Meanwhile, Javanese entrepreneur implements family values, spirituality, innate, paternalism, creativity, deliberation, and harmony. Finally, Madurese entrepreneur emphasizes obedience/surrender to parents, fraternity, and natural behaviour.
\end{abstract}

Keywords: ethnic entrepreneurial characteristics; ethnic entrepreneurial values; MSEs.

Received: August 1, 2020; Accepted: August 31, 2020; Published April 30, 2021

*Corresponding author

Email: elsye.tandelilin@gmail.com

To cite this document:

Tandelilin, E. (2021). An exploration of ethnic entrepreneurial values and characteristics in MSEs. BISMA (Bisnis dan Manajemen), 13(2), 148-162. https://doi.org/10.26740/bisma.v13n2.p148-162.

\section{INTRODUCTION}

A critical contributor to socio-economic growth and development is entrepreneurship. Entrepreneurship activities are considering creating millions of job opportunities and creating various goods and services that increase national welfare and competitiveness (Zahra et al., 1999). The essence of entrepreneurship is initiating change through creativity and innovation. Markets, consumers, and new jobs are created through innovation and organizational renewal, which positively impacts the economic and social systems of various industrial sectors, regions, 
An exploration of ethnic entrepreneurial values and characteristics in MSEs

and nations. A report from the BPS (2018) shows that micro, small, and medium enterprises (MSMEs) on economic growth are enormous. In general, MSMEs are the backbone of various countries, including Asia Pacific countries, because MSMEs are the drivers of economic growth and innovation. In Indonesia, the number of MSMEs is $99 \%$ of all businesses, provides $89 \%$ of jobs in the private sector, and contributes $60 \%$ of GDP. Micro and small businesses (MSEs) in Indonesia experienced growth from year to year. Figure 1 presents the number of MSEs in Indonesia in 2014-2018.

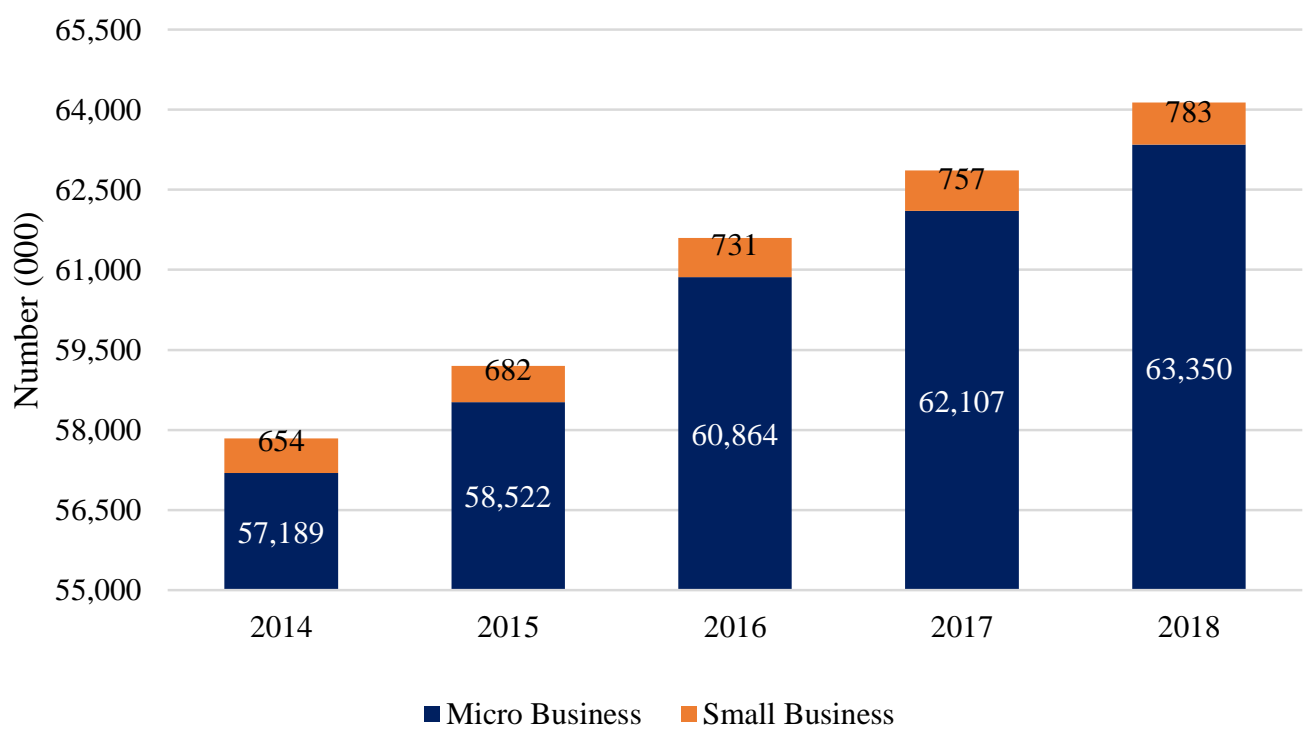

Figure 1. The Number of MSEs in Indonesia Period 2014-2018

Source: Kemenkopukm (2020)

Figure 1 shows that the number of MSEs has increased slightly from 2014 to 2018. However, in 2016 there was a relatively significant increase for both micro and small businesses, about 2.341.591 and 49.525. Specifically, micro and small businesses in Surabaya were spread in thirty districts. Surabaya is a multiculturalism city where many ethnics work as a businessman. The three significant ethnicities in Surabaya are Javanese, Madurese, and Chinese. The rest is the other ethnic groups such as Arabic, Balinese, Batak, Bugis, Manado, Minangkabau, Dayak, Toraja, Ambon, and Aceh or foreigners. Three of those ethnicities are better known as the business people in our society. Nevertheless, the way they do business is different. Each ethnicity has different values, and it determines how they earn business success (Syam, 2018).

Although the MSEs data show an increase in number, the failure of MSEs is still relatively high. Therefore, MSE's business sustainability is challenging, especially with the high rate of entrepreneurial failure (Olaison \& Sørensen, 2014). A study in Dar-es-Salaam, Tanzania, in 2010 showed that almost half of startup micro, small, and medium enterprises in developing countries failed within five years, and only a few grew into big businesses (Mgeni, 2015).

Previous research on entrepreneurs implies that countries have a relationship with how to start and develop MSEs business. MSE's growth is related to economic growth, cultural factors, natural resources, and primary industries. Another result also shows that entrepreneurs' 
value structure has a long-lasting, permanent, unique, and diverse country. Therefore, the research results related to entrepreneurial values also vary between countries. There are distinguishable entrepreneurs' values between an ethnic entrepreneur and non-entrepreneurs (Malovics et al., 2015).

Researchers found the role of personal values when an entrepreneur sets growth expectations of his new business and shows why someone creates a new business (Cassar \& Gibson, 2007). Values can be a driver for starting a business and influencing his business success. This statement supports the expectancy-value theory of Feather (1995), which postulates that a person's values will direct the individual to take appropriate action. Feather (1995) also assumes that values are like personal needs that influence behaviour to achieve achievement. Therefore, it is necessary to understand the values of an entrepreneur and how these values influence their behaviour to succeed in business.

Entrepreneurship can be discussed from individual, environmental, and corporate approaches. Entrepreneurs have a pragmatic approach at the individual level by equalizing entrepreneurship, business ownership, and self-employment. Various studies at the individual level show a relationship between values, beliefs, and behaviours. The logical explanation from a national culture view is that the values and beliefs are embedded in it to influence various behaviours, including deciding to become an entrepreneur rather than others (Mueller et al., 2002). According to the psychological approach, specifics traits have also identified certain attributes of entrepreneurs who have high emotional quotient that distinguish them from others who were not entrepreneurs (Chell et al., 2008).

The business's success is one indicator of entrepreneurial activity performance. It is also often determined by the entrepreneur's character. The statement supports the McClelland (1976) theory which implies that entrepreneurial characteristics can identify the characteristics that motivate individuals to start a new business and contribute to their business success. Moreover, some entrepreneurial characteristics distinguish an entrepreneur from a nonentrepreneur. It means someone who has entrepreneurial characteristics can become a more successful entrepreneur than individuals who have not (Anggadwita \& Mustafid, 2014).

Personal characteristics (known as entrepreneurial characterization) also play an essential role in forming a new business. (Andersson \& Tell, 2009) find a direct relationship between managerial/entrepreneurial characteristics and entrepreneur success. The opinion supports (Reijonen \& Komppula, 2007) focuses on factors that affect business performance. The result showed that the entrepreneur characteristics influence business performance.

Every business founder has different characteristics that influence them to manage a business and respond to the environment. The characteristics of entrepreneurs in small enterprises are strongly related to their entrepreneurs. In some previous studies, individual characteristics determine business success (Taormina \& Sammi, 2007). According to Entrialgo et al. (2000), entrepreneurial characteristics (individual) significantly affect an entrepreneur's success. Entrepreneurial characteristics as a specific set of traits that distinguished entrepreneurs from the general population (Robbins \& Judge, 2017). Another result from Andersson \& Tell (2009) identifies that those individual characteristics affect small firms' growth. Some characteristics encourage entrepreneurs to achieve success, such as the need for 
An exploration of ethnic entrepreneurial values and characteristics in MSEs

achievement, internal locus of control, and risk-taking propensity (Chell et al., 2008). It means that a successful entrepreneur often shows these values and characteristics.

The purpose of this study is to explore the detailed information related to the values and characteristics of Chinese, Javanese, and Madurese entrepreneurs in MSEs. Research results are expected to contribute to organizational behaviour and entrepreneurship concept, especially those related to entrepreneurial values and characteristics.

\section{Entrepreneurship}

Each country has a different definition of entrepreneurship (Mueller et al., 2002). Chell et al. (2008) explained various definitions of entrepreneurship. One of the definition postulate that entrepreneur as a person who sees opportunities and is determined to realize them through the creation of an organization and how a new businesses independently respond to current opportunities is another sense of entrepreneurship (Bygrave \& Hofer, 1992). In contrast to the two previous definitions, an entrepreneur's readiness to act is determined jointly by prior experience and the perception of current opportunities. Furthermore, general readiness is a precondition for starting a business. Entrepreneurs are also seen as the interaction of four dimension is personal characteristics of the entrepreneur (usually individual), strategies to enter the competition, pull and push factors (usually related to the environment) and actions taken by entrepreneurs to realize the company's existence (usually related to the business process (Chell et al., 2008).

According to Robbins \& Judge (2017), entrepreneurship as a process to build new ventures, generally in answer to particularly demanding. The entrepreneur is looking for opportunities by creating new products/services by changing, revolutionizing, and transforming. This opinion in line with other's opinion that entrepreneurs are a person who pursues opportunities even if there are problems and threats in vary situation (Schermerhorn \& Bachrach, 2015). Hence, a review of the literature reveals the importance outlook of entrepreneurship. The definitions imply that entrepreneurs can see opportunities to pursue profit by creating a business, managing and utilizing their resources, and taking risks. Even the ability to innovate (create products/services regardless of lack of resources). Moreover, Chell et al. (2008) stated that to pursue the vision needs the passion and commitment to lead others in the pursuit of that vision.

Most of Indonesia's entrepreneurs are categorizing as MSMEs. Undang-Undang Republik Indonesia No.20/2008 describes micro and small businesses as productive business owned by individuals or business entities that meet the criteria for micro-business as stipulated in this law (OJK, 2008). For example, the micro-business asset should be 300 million rupiahs and a turnover asset of about 50 million.

Meanwhile, a small business is a productive business carried out by individuals or business entities that do not have subsidiaries or branch companies. Small business is owned, controlled, or become a part (directly or indirectly) of medium-sized or large businesses with an asset of about 50 million-500 million and turnover about 300 million- 2.5 billion rupiahs.

A medium business is a productive economic business that carried out by individuals or business entities, not become subsidiaries or own branch companies, controlled, or become a part either directly or indirectly with a small business or large business with asset about 500 million- 10 billion and turnover about 2.5 billion-50 billion rupiahs. Each country has different 
criteria for small and medium enterprises in terms of turnover and the number of workers employed (kemenkopukm, 2020).

\section{Entrepreneurial Values}

Halisa et al. (2007) stated that values are part of the culture. It means that culture is a transmission of norms, beliefs, and values in a society and lasts from generation to generation. Culture shows a shared way of life in particular community groups. To understanding a person's behaviour, someone must understand his/her value first. Value is invisible because of one's beliefs about right and wrong, sound, and evil (Robbins \& Judge, 2017).

Specifically, empirical research demonstrates a direct relationship between entrepreneurship and value (Halisa et al., 2007). The entrepreneur's and non-entrepreneurs values are quite different. Entrepreneurship is also the process of starting new businesses, generally in response to opportunities, and entrepreneurs are pursuing opportunities by changing, revolutionizing, transforming, or introducing new products or services (Robbins \& Judge, 2017). The entrepreneurial value concepts and propositions can be applied in the MSEs context and defined as the entrepreneur values in managing his business to achieve success.

Robbins \& Judge (2017) postulated the relationship between personality and values, which implies that the person's values are mostly a genetically transmitted trait. The argument explains that each ethnic group has different values formed from heredity and the environment they lived. Indonesia is a multicultural country with a diverse ethnic profession as an entrepreneur. However, each ethnic group shows different ways of doing business according to their values (Rohmah et al., 2017).

\section{Entrepreneurial Characteristics}

Recent empirical evidence demonstrates that the Chinese entrepreneurial characteristics in Bekasi City are confucianism values that are applied through hongsui. Similarly, Chinese traders' behaviour in the Jember Regency shows that the dominant Chinese values and characters are persistent, keeping promises, and intense fighting spirit (Rohmah et al., 2017). It is different from Javanese values and characters that emphasize family relationships (Handaru et al., 2015). Simultaneously, the dominant values and characters of Madurese are adherence to religion, parental rules, and strong resilience (Rahmasari \& Mahajudin, 2017). The studies of the three ethnic groups in various cities indicate differences in each entrepreneur's values and characteristics, influencing how they run their business.

The significant variations in intercultural entrepreneurial activities and cultural values strongly influence entrepreneurial behaviour (Chell et al., 2008). McGrath et al. (1992) also compared entrepreneurs and non-entrepreneurs and found significant differences in their values. The contradictive postulates state that the unique environment (close family) and broad social context (national culture) can influence career choices as prospective entrepreneurs (Robbins \& Judge, 2017).

The recent empirical evidence demonstrates that a successful entrepreneur shows specific characteristics. Those characteristics are: (1) internal locus of control, people believe they have control for their destiny; (2) high energy level, persistence and work hard to achieve the highest level; (3) self-confidence, competence to make the best decision; (4) tolerance for ambiguity, risk-taker and tolerance for the high degree of uncertainty; (5) self-reliance and desire for 
An exploration of ethnic entrepreneurial values and characteristics in MSEs

independence, freedom and independence in work; (6) high need for achievement, motivated to achieve challenging goals; (7) flexibility, willing to adapt the environment changing; and (8) passions and action orientations, always proactive in action (Schermerhorn \& Bachrach, 2015).

Current research also presents that entrepreneurial characterization differs between countries and cultures (Robbins \& Judge, 2017). It proves that each culture has different entrepreneurial characteristics. Each entrepreneur has different characteristics in term of business passion, tenacity of failure, confidence, self-determination, risk management, opportunities, ambiguity tolerance, initiative, need for achievement, detail orientation, perfectionism, perception of passing the time, creativity, visionary, and motivation to success (Chell et al., 2008). The entrepreneur's attitude and behaviour are congruent with their values and how they react toward something/someone/certain events.

\section{Chinese Business Value and Characteristics}

In Chinese society, the value of family collectivism is inherently powerful (Efferin \& Hopper, 2007). The values are derived from confucianism values (Suryadinata, 1997) and the Taoist moral law embraced by Confucian teachings. These values emphasize social order, harmony, social relations based on jen's values included in the chung values, and shu (Suryadinata, 1997). Jen's values are the values that emphasize loving others (loving others as oneself), chung is the value of honesty and sincerity. One of the values that are considered the most important for Chinese people is hsiao (filial piety). This value is usually applied extensively in various aspects associated with social responsibility, mainly shown through the character of respect, obedience, loyalty to superiors (for employees/subordinates), wise, and caring leaders towards their subordinates (for leaders/superiors).

Large families or the same lineage groups are considered concentric circles by Chinese society, the resources owned by these families must be protected and enhanced to grow selfsufficiency. Therefore, friends and acquaintances have trust following the mutual interdependence in the values of guanxi-known as ethnic-based networks that aim to help each other and protect family resources (Efferin \& Hopper, 2007).

Confucianism values to entrepreneurs of Chinese descent are firm, especially the patrimonial business style. The owner has full power, and employees consider the company a family asset and business that manages family. The owner of employees always instils prudence value and money consciousness. Top management positions are given to the trusted lineage's nuclear family/family members. The leadership style applied is more autocratic but paternalistic. $\mathrm{Li}$ and Hsiao's values are also firmly attached to Chinese entrepreneurs and employees so that it is relatively easy to build a stable discipline and hierarchical character. However, these values can produce nepotism behaviour, in-groups in the organization, nonfamily members, have limited authority, the confidentiality of information, subjective evaluation of performance, and limited promotional opportunities (Efferin \& Hopper, 2007).

In Chinese business management, hierarchical decisions such as termination, recruitment, rewarding, discipline, and employee evaluation build on friendship, trust, emotional ties, and loyalty rather than actual performance appraisal. It describes that the values held by Chinese businesspeople greatly influence business character and business management. In Chinese organizations, legitimate cultural controls are easily formed and tend to replace bureaucratic control. The central values derived from $l i$ and hsiao's values are qin 
jian, ke ji, qin fen, and jing shen. Qin jian (frugality) value emphasizes saving, conserving resources and displays wealth with humility. Ke ji's (asceticism) value emphasizes the desire to control wealth, strength, pleasure, and fulfil social responsibility. Qin fen value advocates perseverance seeks knowledge and wisdom. Jing shen's value embraces caution and foresight (Efferin \& Hopper, 2007).

\section{Javanese Business Values and Characteristics}

About $41.71 \%$ of Indonesia's total population is Javanese, spread in various regions of Indonesia (Suryadinata, 1997). Most Javanese people also work as entrepreneurs (Rademakers, 1998). Javanese culture is widely known as innate-rude and physically-spiritually balance. Natural means are pure, subtle, polite, beautiful, wise, civilized, and calm. Rough means the opposite: impolite, rude, uncivilized, discuss the actions, movements, postures, and external speech of individuals. The inner nature is questioned in Javanese emotional life. The right combination of innate-rude and deep nest produces three values: the layered social order, paternalism, social harmony, and mysticism (Wijaya et al., 2017).

Humanity is one of the dominant values in Javanese culture. This value application is to humble oneself politely, show the correct behaviour/character, know the position, behave, and choose words correctly to communicate with others. Javanese culture emphasizes social hierarchy, which involves rigid rules, social harmony, and spiritualism. Social hierarchy manifests in two core values: etiquette and Javanese language. Javanese etiquette provides a set of behaviour to interact with people from different social hierarchy levels, be humble, and polite in communication with others who have the same status or higher (Efferin \& Hopper, 2007).

Paternalistic relations between leaders and followers are known as paternalism (Rademakers, 1998). Paternalism describes an ideal father who is highly respected or a figure who has charisma and is obliged to take care of his subordinates and has hands and hearts to guide his family members/followers by displaying characteristics such as virtue and wisdom. The commandments are one of the values highlighted in Javanese culture. Commandments are conditions where there are no open expressions, opinions, and feelings to keep everybody in harmony. To achieve harmony, one must prioritize group members and implement collective decision-making (deliberations), consensus, and cooperation. Mutual assistance and burden sharing, including family and community, represent the concept of harmony. The value of social harmony reflects unselfish behaviour and respect for the wider community (Efferin \& Hopper, 2007).

Maintaining a harmonious relationship with God for a peaceful life is a mystical belief of the Javanese. Javanese believe that ancestors, places, and spirits can communicate. The beliefs require thanksgiving, a communal feast on actual events that symbolize the mystical and social unity of the participants. All Javanese values build their character and behaviour in doing business (Efferin \& Hopper, 2007).

\section{Madurese Business Values and Characteristics}

Madurese is known as an ethnic who likes to migrate. Economic and environmental difficulties become the trigger of this behaviour. They migrate to various regions in Indonesia. In other regions, most Madurese works in the private sector and services. The Madurese are 
An exploration of ethnic entrepreneurial values and characteristics in MSEs

known for their distinctive, stereotypical, and stigmatic culture. They have specific cultural values different from other ethnicities. The specificities of Madurese values are obedience and submission. Hierarchically, these values apply in life by referring to four figures, namely father, mother, teacher, and government leaders (buppa, babbu, guru, and ban rato). Islam religiosity strongly influences these values. The values are applied in daily life as binding normative rules. Therefore, neglect or violations committed intentionally, and the perpetrators will be subject to social and cultural sanctions. The value of brotherhood is very thick in Madurese culture. The value can be understood from the phrase oréng dhaddhi taretan, taretan dhaddhi oréng (other people can be/are considered your siblings). The value is implemented because of similarities or conformities such as heredity or kinship ties (genealogically), belief systems (religion and rhythmicity), and language similarity (Wijaya et al., 2017).

Madura Island's barren and topographical conditions establish the unique culture and character of the Madurese. The persistence to survive makes Madurese have unique characters, such as brave, hard-hearted, resilient, thrifty, confident, defensive, open, dignity and high selfesteem. Other ethnic groups often interpret these characters/behaviours through subjective prejudice known as stereotypes. The stereotypes are built on subjective prejudices with the generality of particular groups of people based on the behaviour exhibited by a small group member of the community. Stereotypes can have positive or negative meanings. The stereotypes that emerge in the Madurese community include rude, disrespectful, swindler, and selfish. The Madurese characters include: (1) ejhin-describes the character of independence; (2) gherra (rough and rigid); (3) koko (sturdy) illustrates the determination of Madurese in holding beliefs, convictions, opinions, words; and (4) saduhuna (just the way you are) (Samudji et al., 2017).

\section{METHODS}

This qualitative study uses a case study approach to understand phenomena such as behaviour, perception, motivation, and holistic action, employing descriptions in words and language in an exceptional natural context and utilizing various natural methods. Multi sources data are used in this study to support the validity and reliability of the data obtained. Data are collected through unstructured interviews with informants, field notes, and observations. Interviews are recorded and then written in the manuscript. The informants interviewed six entrepreneurs from Chinese, Javanese, and Madurese ethics ( 2 informants for each ethnic) who stay in Surabaya.

\section{RESULTS AND DISCUSSION Informants Profile}

The results demonstrate that each informant has differences in ethnics, type of business, age, and the period of running the business. Informant profiles are described in Table 1. Based on Table 1, six informants consist of three ethnics-Chinese, Javanese, and Madurese. Mr Y is a Chinese, 30 years old, has a food and beverage business (coconut drinks), the business tenure is eight years. The second informant, $\mathrm{Mr} \mathrm{X}$, is a Chinese, 37 years old, who has a beauty salon business for five years. The third and fourth informants (Mrs W and Mrs Z) are Javanese, 50 and 45 years old. Mrs W runs a batik boutique business for 25 years, and Mrs Z has traditional snacks for 20 years. The two last informants (Mrs A and Mr B) are Madurese, running their 
business for 35 and 10 years. Mrs A is 56 years old, has a chicken and duck business, while $\mathrm{Mr}$ $\mathrm{B}$ is 33 years old, running the Soto Madura business.

Table 1. Informant Profile

\begin{tabular}{llccc}
\hline Informant & Ethnics & Age & Business Type & Business Period (years) \\
\hline Mr Y & Chinese & 30 & Drinks & 8 \\
Mr X & Chinese & 37 & Salon & 5 \\
Mrs W & Javanese & 50 & Batik Boutique & 25 \\
Mrs Z & Javanese & 45 & Traditional Snack & 20 \\
Mrs A & Madurese & 56 & Chicken \& Duck & 35 \\
Mr B & Madurese & 33 & Soto Madura & 10 \\
\hline
\end{tabular}

\section{Analysis of Chinese Values and Characteristics}

Guanxi values in Chinese people's daily lives are informal and less hierarchical. This value applies in a common approach and is based on trust in someone (Wijaya et al., 2017). The values are built on Confucian teaching. In doing business, Indonesian Chinese is very dominant in applying guanxi values and indirectly binds people in mutual obligations, trust, understanding, attitudes towards long-term business, and social relations (Hwang et al., 2009). As Mr Y explained: "When I graduated from college and wanted to start a business, I did not have the capital. At that time, my mother had a recipe for coconut drinks that my family loved. However, to make it into a business, I did not have enough money. One of the uncles of my mother loaned me capital to start this business."

Mr X recognized a similar experience: "After a long time working as a salon employee, I wanted to open my salon, but I did not have enough money to rent a place and buy salon equipment. My brother offered me the initial capital to start this salon business." This statement explains that the implementation of the guanxi values is still applying in the Chinese community, which can uplift the socio-economic lives of those closest to them-the implementation of the values based on a strong sense of brotherhood. The application of guanxi values is inseparable from the personal trust created in large families and is widely implementing in managing a business.

The value of personal trust is also very tight in the business management of Chinese ethnicity. Mr Y argues that "For jobs that are considered confidential such as concocting herbs or recipes, only entrusted to be done by close family (grandfather, grandmother, father, mother or child) to protect the sustainability of the family business. While other jobs are lifting to the employees." Chinese society is a society that prioritizes lineage, which is concentrated in the family environment. People in China see family resources as a treasure to be protected and developed to produce self-reliance/self-sufficiency (Fei, 1999). Therefore, each can unite through mutual trust and mutual assistance (Redding \& Micheel, 2007). Fei's (1999) statement is congruent with the statement of Mr Y: "For the purchase of the main ingredients, I do it myself, while for making my mother does drinks, my employees assist the others." His mother justified the statement. Mr X also applies the same value as he said: "For salon bookkeeping, cashiers, and purchasing salon equipment and materials, I do by myself, my employees help cleaning the salon, washing equipment, washing consumer hair, hair curling, and several other activities."

The Chinese entrepreneur also upholds honesty in doing business because they focus on long-term harmonious relationships. This value was revealing from the statement of two 
An exploration of ethnic entrepreneurial values and characteristics in MSEs

informants: "If you want consumers to come back again, we must be honest in doing business. Do not deceive consumers because it will destroy our business in the long run. Indeed, it looks fortunate in the short term, but bad news about our business will spread by word of mouth."

The Chinese entrepreneur also upholds honesty in doing business because they focus on long-term harmonious relationships. This value was revealing from the statement of two informants: "If you want consumers to come back again, we must be honest in doing business. Do not deceive consumers because it will destroy our business in the long run. Indeed, it looks fortunate in the short term, but bad news about our business will spread by word of mouth."

Saving and sparing are the central values in Chinese society because Chinese entrepreneurs are very future-oriented (long-term orientation). As stated by $\mathrm{Mr} \mathrm{Y}$ : "When my business has started to develop, I always manage my spending so as not to exceed the budget that I have made. I always save money to develop my business. My mother always reminds me to save money and to spare money. "Mr X also recognized: "My expenses are under control; I handle the work by myself so that there is no need to recruit many employees." These results supported the previous postulate related to Chinese money consciousness in managing a business. Mr X's employee, Mr O, confirmed: "The owner handles all of the salon materials and equipment handled by himself. The boss is also an expert in costing and issuing money."

\section{Analysis of Javanese Values and Characteristics}

The two Javanese informants (Mrs W and Z) have different types of businesses. Mrs W started her fashion business from her sewing hobby, which had been developing since she was in college, intending to earn extra money. After graduating, she made her hobby into a business by accepting stitches at home to collect capital; as she stated: "Using the necessary resources, I started a stitching business. The sewing machine belongs to my mother, and I hope to have several sewing machines also workers to help me." Hard work and perseverance for about five years finally paid off. Mrs W managed to have her own fashion business with 12 employees.

In Javanese culture, the value of trust is consistently applying in Mrs W's everyday life, including in managing her business. As she informed: "When I started recruiting employees, I was determined to teach them various sewing skills. I believe they will produce good stitches. However, after the business began to bustle and the employees began to be skilled in sewing, the employees resigned to open their own business. This incident makes me down because I had put confidence in teaching my sewing skill to them, finally was betraying. I am outraged and stressed, but my father and mother's support triggers me to get up and think creatively. I try to use embroidery skills so that my stitching is more creative and different from my former employee."

After marriage, the business of Mrs W began to develop into a clothing boutique. The boutique management is assisting by her husband, who has painting skills. Finally, the clothing business is combined with painting, resulting in unique stitching products that are difficult to replicate. In managing her employees, Mrs W always applies inherent and spiritual values, as expressed by her: "I ask my employees to respect their elders and use the soft Javanese language in communication. If employees communicate using standard Javanese language (coarse), I will reprimand them by answering in polite Javanese language. The approach cannot change the employee attitude directly; therefore, I do it continuously over time. Finally, 
my employees began to understand my way as a gentle rebuke to them. I also remind every employee to pray and celebrate every traditional and religious celebration they have."

Mrs Z also implements the same values as she said: "I try to protect my employees, teach them always to speak politely/innate and respect each other's differences of opinion. If I want to decide on work, I always invite them to get a collective agreement/consensus. When a conflict increases, I always ask them to prioritize kinship to solve and always live harmoniously at the workspace. Each employee has a different opinion, especially arguments between the young and the older; therefore, mutual respect must be developing." The statements demonstrate a Javanese value application, including perseverance, hard work, trust, creativity, innate, spiritual, paternalism, respect, and deliberation. The results support the previous postulate that Javanese culture emphasizes social hierarchy, which involves rigid rules, social harmony, and spiritualism where its manifestations are in two central values known as etiquette and Javanese language, and other characteristics such as kinship, virtue, harmony, consensus, cooperative, paternalism, and spiritualism.

\section{Analysis of Madurese Values and Characteristics}

Madura tribe is known as a dynamic ethnic and a businessman. Most Madurese businesses pass on to their children, and children usually obey parents' wishes. As stated by Mrs A: "My mother used to sell chicken and duck at the traditional market. When I was a teenager, I help her selling at the traditional market. Even now, I just obediently told all of my children to help me sell at the same traditional market. I hope if I retired from my business one day, my children would continue my business. I am looking for business sustainability". A similar experience is recognized by Mr B: "I also continued the business of selling Soto Madura from my parents. At that time, my father had a health problem because of cholesterol. I was deciding to continue his business. My brothers and sisters also sell Soto Madura, but in different places." These statements describe that the value of obedience to the parents is still very dominant in Madurese. The result supports the previous statement that the dominant values of Madurese are obedience and submission. These values are also applying to parents' business choices.

The value of brotherhood is well known in the Madurese community too. The value is implying to the habits of Madurese who have been successful outside Madura Island to invite relatives, friends, and their close community to come to the same city/place. The habits create many Madurese communities in various locations, such as in Probolinggo, Pasuruan, Jember. Both informants implement the values too. As they said: "In running the business, we assisted several relatives we invited from Madura. Besides helping them economically, we also feel comfortable working with people who have the same values and characters." The illustrates the orêng dhaddhi tarêtan, tarêtan dhaddhi orêng (other people can be/are considered as your siblings while the siblings themselves can be/are considering as others) value. It means that although people do not have biological siblings if they have Madurese essential character, they can be easily treated as their siblings (pseudo-kinship). On the contrary, siblings can be treated like other people if there is a mismatch with Madurese value in perspective, opinions, and assumptions (Moynihan et al., 1990).

Negative stereotypes about the Madurese are very attached to Surabaya's people, although not all Madurese have these stereotypes, especially in business. As Mrs A explained: 
"I always try to get my customers repeated buying. Lose customers means losing money. I am also afraid of cheating customers due to sin, so if the products are expensive, I will say it is expensive, and vice versa. I always tell the truth to make my customer satisfied." Polite communication is also the value of $\mathrm{Mr} \mathrm{A}$ in doing business. A similar value is owned by $\mathrm{Mr}$ B: "I have been running my father's business for ten years. I always remember his value of being honest in selling to get much luck. I also always try to provide fast service for every customer." All the explanations are in line with their family opinions, such as being honest and not rude to the customer in managing the business. It demonstrates that negative stereotypes about Madurese in doing business are not always accurate and are merely casuistic. Table 2 presents the comparison of entrepreneurial values and characteristics between ethnicities.

Table 2. The Comparison of Entrepreneurial Values and Characteristics of Chinese, Javanese, and Madurese

\begin{tabular}{ccc}
\hline Chinese & Javanese & Madurese \\
\hline Perseverance & Applying family values & Obedience to parents \\
Hard work & Spiritual & Fraternity values \\
Guanxi & Innate & Friendliness \\
Honesty & Paternalism & Honesty \\
Personal trust & Creativity & Pseudo-kinship \\
Confucianism values & Deliberation & \\
& Harmony & \\
\hline
\end{tabular}

\section{CONCLUSIONS}

For MSEs, it is not easy to run a business successfully, and its entrepreneur's values and characteristics greatly influence its success. The values and characteristics of each ethnicity are different, so that the way of doing business is also different between ethnicities. Chinese, Javanese, and Madurese entrepreneurs display different values and characters in managing a business. Indonesian Chinese entrepreneurs are dominant in perseverance, hard work, guanxi, honesty, personal trust, and confucianism values. Simultaneously, Javanese are dominant in applying family values, spiritual, innate, paternalism, creativity, deliberation, and harmony. The Madurese emphasizes obedience/surrender to parents and fraternity values. The results also present that not all Madurese have negative stereotypes.

The values and characteristics such as honesty, friendliness, and being forthright are part of Madurese characteristics. There are some similarities between the three ethnics. Chinese and Javanese have the same spiritual values, while Javanese and Madurese have the same values of kinship/brotherhood. The Chinese and Madurese have similarities in the value of honesty, and the three ethnics have the same values of brotherhood/family values/guanxi.

The research results are expected to provide several implications. First, an entrepreneur's success is influenced by their values and characteristics. These points differ between ethnicities, which causes the different ways of doing business. Second, the results of this study also contribute to providing preliminary information for further research. Third, this study provides an overview of the ways of doing business of the three analyzed ethnic groups (Chinese, Javanese, and Madurese) in Indonesia.

This study has several limitations. First, this study focuses only on the micro and small business sectors, while medium-scale businesses are not included in this study. The number of samples is relatively small, so it cannot be generalized to all Chinese, Javanese, and Madurese 
entrepreneurs in Surabaya. Recommendations for conducting the future study are using a more significant number of informants or respondents, varying the business categories, and using mixed methods to get more optimal results.

\section{REFERENCES}

Andersson, S. \& Tell, J. (2009). The Relationship Between the Manager and Growth in Small Firms. Journal of Small Business and Enterprise Development, 16(4), 586-598. https://doi.org/10.1108/14626000911000938.

Anggadwita, G. \& Mustafid, Q. Y. (2014). Identification of Factors Influencing the Performance of Small Medium Enterprises (SMEs). Procedia - Social and Behavioral Sciences, 115, 415-423. https://doi.org/10.1016/j.sbspro.2014.02.448.

BPS. (2018). Laporan Perekonomian Indonesia 2018. Retrieved December 152020 from https://www.bps.go.id/publication/2018/09/17/bae4f1fa633a50bac480775b/laporanperekonomian-indonesia-2018.html.

Bygrave, W. D. \& Hofer, C. W. (1992). Theorizing about Entrepreneurship. Entrepreneurship Theory and Practice, 16(2), 13-22. https://doi.org/10.1177/104225879201600203.

Cassar, G. \& Gibson, B. (2007). Forecast Rationality in Small Firms. Journal of Small Business Management, 45(3), 283-302. https://doi.org/10.1111/j.1540-627X.2007.00213.x.

Chell, E., Wicklander D. E., Sturman S. G., \& Hoover L. W. (2008). The Entrepreneurial Personality: A Social Construction: Second Edition. London: Routledge. https://doi.org/10.4324/9780203938638.

Efferin, S. \& Hopper, T. (2007). Management Control, Culture, and Ethnicity in a Chinese Indonesian Company. Accounting, Organizations and Society, 32(3), 223-262. https://doi.org/10.1016/j.aos.2006.03.009.

Entrialgo, M., Fernández, E., \& Vázquez, C. J. (2000). Psychological Characteristics and Process: The Role of Entrepreneurship in Spanish SMEs. European Journal of Innovation Management, 3(3), 137-149. https://doi.org/10.1108/14601060010334894.

Feather, N. T. (1995). Values, Valences, and Choice: The Influence of Values on the Perceived Attractiveness and Choice of Alternatives. Journal of Personality and Social Psychology, 68(6), 1135-1151. https://doi.org/10.1037/0022-3514.68.6.1135.

Fei, F. C. (Ed.). (1999). Chinese Theories of Theater and Performance from Confucius to the Present. Michigan: University of Michigan Press. https://www.press.umich.edu//16388.

Halisa, M., Ozsabuncuoglub, I. H., \& Ozsagirb, A. (2007). The Values of Entrepreneurship and Factors That Effect Entrepreneurship: Findings from Anatolia. Serbian Journal of Management, 2(1), 21-34. http://www.sjm06.com/SJM\%20ISSN14524864/2_1_2007_May_1-99/2_1_21-34.pdf.

Handaru, A. W., Pagita, M. P., \& Parimita, W. (2015). Karakteristik Entrepreneur melalui Multiple Diskriminan Analisis (Studi pada Etnis Tionghoa, Jawa dan Minang d Bekasi Utara). JRMSI - Jurnal Riset Manajemen Sains Indonesia, 6(1), 351. https://doi.org/10.21009/jrmsi.006.1.02. 
An exploration of ethnic entrepreneurial values and characteristics in MSEs

Hwang, D. B., Golemon, P. L., Chen, Y., Wang, T. S., \& Hung, W. S. (2009). Guanxi and Business Ethics in Confucian Society Today: An Empirical Case Study in Taiwan. Journal of Business Ethics, 89(2), 235-250. https://doi.org/10.1007/s10551-008-9996-5.

Kemenkopukm (2020). Perkembangan Data UMKM dan UB. Retrieved December 152020 from https://www.kemenkopukm.go.id/data-umkm.

Malovics, É., Farkas, G., \& Vajda, B. (2015). Appearance of Entrepreneurial Values and Strategic Orientations in the Basic Values. International Journal of Business and Management, III(1), 18-35. https://doi.org/10.20472/bm.2015.3.1.002.

McClelland, J. L. (1976). Preliminary Letter Identification in the Perception of Words and Nonwords. Journal of Experimental Psychology: Human Perception and Performance, 2(1), 80-91. https://doi.org/10.1037/0096-1523.2.1.80.

McGrath, R. G., MacMillan, I. C., \& Scheinberg, S. (1992). Elitists, Risk-Takers, and Rugged Individualists? An Exploratory Analysis of Cultural Differences between Entrepreneurs and Non-Entrepreneurs. Journal of Business Venturing, 7(2), 115-135. https://doi.org/10.1016/0883-9026(92)90008-F.

Mgeni, Othumary T. (2015). Impact of Entrepreneurial Leadership Style on Business Performance of SMEs in Tanzania. Journal of Entrepreneurship \& Organization Management, 04(2), 71-77. https://doi.org/10.4172/2169-026X.1000142.

Moynihan, J. A., Ader, R., Grota, L. J., Schachtman, T. R., Cohen, N. (1990). The Effects of Stress on the Development of Immunological Memory following Low-Dose Antigen Priming in Mice. Brain, Behavior, and Immunity, 4(1), 1-12. https://doi.org/10.1016/0889-1591(90)90001-7.

Mueller, S. L., Thomas, A. S., \& Jaeger, A. M. (2002). National Entrepreneurial Potential: The Role of Culture, Economic Development, and Political History. Advances in Comparative International Management, 14, 221-257. https://doi.org/10.1016/s07477929(02)14037-6.

OJK. (2008). Undang-Undang Republik Indonesia Nomor 20 Tahun 2008 Tentang Usaha Mikro, Kecil, Dan Menengah. Retrieved 20 April 2020 from https://www.ojk.go.id/sustainable-finance/id/peraturan/undangundang/Documents/UndangUndang\%20Nomor\%2020\%20Tahun\%202008\%20Tentang\%20Usaha\%20Mikro,\%20 Kecil,\%20dan\%20Menengah.pdf.

Olaison, L. \& Sørensen, B. M. (2014). The Abject of Entrepreneurship: Failure, Fiasco, Fraud. International Journal of Entrepreneurial Behaviour and Research, 20(2), 193-211. https://doi.org/10.1108/IJEBR-09-2013-0143.

Rademakers, M. F. L. (1998). Market Organisation in Indonesia: Javanese and Chinese Family Business in the Jamu Industry. Organization Studies, 19(6), 1005-1027. https://doi.org/10.1177/017084069801900605.

Rahmasari, D. \& Mahajudin, M. (2017). Protective Factors Determine Resilience in Madurese Ethnic Adolescent. International Journal of Humanities and Social Science Invention, 6(4), 48-55. http://www.ijhssi.org/v6i4(version\%202).html.

https://journal.unesa.ac.id/index.php/bisma/index 
Redding, G. \& Micheel A, W. (2007). The Future of Chinese Capitalism: Choices and Chances (First Edit). Oxfors University Press. https://www.amazon.com/Future-ChineseCapitalism-Gordon-Redding/dp/0199218137.

Reijonen, H. \& Komppula, R. (2007). Perception of Success and its Effect on Small Firm Performance. Journal of Small Business and Enterprise Development, 14(4), 689-701. https://doi.org/10.1108/14626000710832776.

Robbins, S. P. \& Judge, T. A. (2017). Organizational Behavior, Seventeenth Edition, Global Edition. Pearson Education Limited. https://www.pearson.com/us/highereducation/product/Robbins-Organizational-Behavior-17th-

Edition/9780134103983.html.

Rohmah, A. N., Widodo, J., \& Djaja, S. (2017). Perilaku Wirausaha Pedagang Etnis Cina di Jalan Samanhudi Kabupaten Jember. Jurnal Pendidikan Ekonomi: Jurnal Ilmiah Ilmu Pendidikan, Ilmu Ekonomi Dan Ilmu Sosial, 11(1), 8. https://doi.org/10.19184/jpe.v11i1.4990.

Samudji, S., Haryono, A., \& Sofyan, A. (2017). The Values of Nationalism and Behavioral Conducts in Madurese Local Wisdom (MLW). The International Journal of Social Sciences and Humanities Invention, 4(9), 4001-4012 https://doi.org/10.18535/ijsshi/v4i9.17.

Schermerhorn \& Bachrach. (2015). Introduction to Management (13th Edition). United State: John Wiley \& Sons.

Suryadinata. (1997). Ethnic Chinese as Southeast Asians (1st Edition). Singapore: Institute of Southest Asian Studies. https://doi.org/10.1007/978-1-137-07635-9.

Syam. (2018). Keberagaman Suku Bangsa di Jawa Timur Perekat Bangsa. Retrieved December 132020 from https://wartawisata.id/2018/06/17/keberagaman-suku-bangsa-di-jawatimur-perekat-bangsa/.

Taormina, R. J. \& Sammi, K. M. L. (2007). Measuring Chinese Entrepreneurial Motivation: Personality and Environmental Influences. International Journal of Entrepreneurial Behaviour \& Research, 13(4), 200-221. https://doi.org/10.1108/13552550710759997.

Wijaya, T., Nurhadi, N., \& M. Kuncoro, A. (2017). Exploring the Problems Faced by Practitioners of Micro, Small, and Medium Enterprises (MSMEs) In Yogyakarta. Jurnal Manajemen dan Kewirausahaan, 19(1), 38-45. https://doi.org/10.9744/jmk.19.1.38-45.

Zahra, S. A., Nielsen, A. P., \& Bogner, W. C. (1999). Corporate Entrepreneurship, Knowledge, and Competency Development. Entrepreneurship and Practice, 23(3), 169-189. https://doi.org/10.1177/104225879902300310. 